REVIEW ARTICLE

\title{
Plant-pathogen interactions: what is proteomics telling us?
}

\author{
Angela Mehta ${ }^{1}$, Ana C. M. Brasileiro ${ }^{1}$, Djair S. L. Souza ${ }^{1,2, *}$, Eduardo Romano ${ }^{1, *}$, \\ Magnólia A. Campos ${ }^{3, *}$, Maria F. Grossi-de-Sá ${ }^{1, *}$, Marília S. Silva ${ }^{4, *}$, Octávio L. Franco ${ }^{5,6, *}$, \\ Rodrigo R. Fragoso ${ }^{4, *}$, Rosangela Bevitori ${ }^{7, *}$ and Thales L. Rocha ${ }^{1, *}$ \\ 1 Embrapa Recursos Genéticos e Biotecnologia, Brasília, Brazil \\ 2 Departamento de Biologia Celular, Universidade de Brasília, Brazil \\ 3 Universidade Federal de Lavras, Brazil \\ 4 Embrapa Cerrados, Planaltina, Brazil \\ 5 Centro de Análises Proteômicas e Bioquímicas, Pós-Graduação em Ciências Genomicas e Biotecnologia, Universidade Católica de Brasília, \\ Brazil \\ 6 Departamento de Biologia, Universidade Federal de Juiz de Fora, Brazil \\ 7 Embrapa Arroz e Feijão, Goiânia, Brazil
}

\section{Keywords \\ bacteria; defence proteins; functional genomics; fungi; mass spectrometry; nematode; pathogenicity proteins; proteomics; two-dimensional electrophoresis; virus}

\section{Correspondence}

A. Mehta, Embrapa Recursos Genéticos e Biotecnologia, PBI, PqEB Av. W 5 Norte Final, CEP 70770-900 Brasília, DF, Brazil Fax: +55 6133403658

Tel: +55 6134484901

E-mail: amehta@cenargen.embrapa.br

*These authors contributed equally to this work

(Received 27 Mar 2008, revised 22 May 2008, accepted 29 May 2008)

doi:10.1111/j.1742-4658.2008.06528.x
Over the years, several studies have been performed to analyse plant-pathogen interactions. Recently, functional genomic strategies, including proteomics and transcriptomics, have contributed to the effort of defining gene and protein function and expression profiles. Using these 'omic' approaches, pathogenicity- and defence-related genes and proteins expressed during phytopathogen infections have been identified and enormous datasets have been accumulated. However, the understanding of molecular plant-pathogen interactions is still an intriguing area of investigation. Proteomics has dramatically evolved in the pursuit of large-scale functional assignment of candidate proteins and, by using this approach, several proteins expressed during phytopathogenic interactions have been identified. In this review, we highlight the proteins expressed during plantvirus, plant-bacterium, plant-fungus and plant-nematode interactions reported in proteomic studies, and discuss these findings considering the advantages and limitations of current proteomic tools.

\section{Introduction}

Plant-pathogen interactions have been studied extensively over the years from both the plant and pathogen viewpoints. An understanding of how plants and pathogens recognize each other and differentiate to establish either a successful or an unsuccessful relationship is crucial in this field of investigation. Looking at

\footnotetext{
Abbreviations

1DE/2DE, one-/two-dimensional electrophoresis; AHL, N-acyl homoserine lactone; Avr, avirulence; CWDE, cell wall-degrading enzyme; EST, expressed sequence tag; GST, glutathione S-transferase; MDL, mandelonitrile lyase; OPG, osmoregulated periplasmic glucan; OsPR-10, rice pathogenesis-related protein class 10; PBZ1, probenazole-inducible protein; PMMoV-S, pepper mild mottle tobamovirus Spanish strain S; PPV, plum pox potyvirus; PR, pathogenesis-related; Prx, peroxiredoxin; RLK, receptor-like protein kinase; RYMV, rice yellow mottle sobemovirus; SOD, superoxide dismutase; TLP, thaumatin-like protein; TMV, tobacco mosaic tobamovirus; TTSS, type III secretion system.
} 
the defence mechanisms in plants, the recognition and signalling events that occur in plant cells in response to microorganism challenge need to be extremely rapid, reliable and specific, and are part of the strategy evolved by plants to survive attacks. The intracellular sensitive perception of pathogens and the recognition of pathogen-associated molecular patterns, such as lipopolysaccharides and flagellin, lead to the activation of the plant basal defence (or resistance), which is the first defence response, and trigger a generic mechanism consisting of plant cell wall thickening, papilla deposition, apoplast acidification and signal transduction and transcription of defence genes [1]. This generic basal defence mechanism has been observed in several incompatible plant-microorganism interactions, and is believed to corroborate the observation that most plants are resistant to invasion by the majority of pathogens. Therefore, successful pathogens must evolve mechanisms to interfere with or suppress basal defence to colonize the host and develop disease.

Superimposed on the basal defence, some plant varieties express resistance proteins that guard against this interference and trigger a specific, genetically defined hypersensitive response and subsequent programmed cell death. The function of the hypersensitive response is to contain the pathogen, and it is typified by various biochemical perturbations, known as generic plant responses, including changes in ion fluxes, lipid hyperperoxidation, protein phosphorylation, nitric oxide generation and a burst of reactive oxygen species and antimicrobial compounds. This rapid incompatibility response effectively puts an end to pathogen invasion and prevents further disease development [1].

With regard to plant pathogens, the capacity to overcome plant defence, by protecting themselves from the oxidative stress activated by the plant in response to pathogen perception, is of extreme importance. Therefore, pathogens induce several genes, such as catalases and superoxide dismutase (SOD), which are responsible for the inactivation of $\mathrm{H}_{2} \mathrm{O}_{2}$ and $\mathrm{O}_{2}{ }^{-}$. The importance of secretion pathways for pathogenicity has also been well established. Effector proteins expressed by the pathogen are predicted to collaborate in the suppression of basal resistance through the modification of specific host proteins. The secretion of extracellular enzymes, such as pectin esterases, polygalacturonases, xylanases, pectato lyases and cellulases, is another essential process for colonization and pathogenicity [2].

With the increase in genomic and postgenomic studies, a large amount of information is available, and advances have been achieved in the understanding of defence mechanisms in plants, as well as the pathogenicity strategies employed by microbial pathogens.
At present, the functional assignment of given proteins is considered to be the main challenge in postgenomic studies. Transcriptional changes do not reflect the complete cellular regulatory mechanism, as post-transcriptional processes which alter the amount of active protein, such as synthesis, degradation, processing and post-translational modification, are not taken into account. Thus, complementary approaches, such as proteome-based expression profiling, are needed to obtain a full picture of the regulatory elements. Moreover, several studies have revealed that the levels of mRNA do not necessarily predict the levels of the corresponding proteins in the cell [3]. The different stabilities of mRNAs and different efficiencies in translation can affect the generation of new proteins. Once formed, proteins also differ significantly in their stability and turnover rate, which makes proteomic investigation even more important.

Proteomics, or the analysis of the protein complement of the genome, provides experimental continuity between genome sequence information and the protein profile in a specific tissue, cell or cellular compartment during standard growth or different treatment conditions. Although the genome defines potential contributions to cellular function, the expressed proteome represents actual contributions. Moreover, by using proteomic approaches, differences in the abundance of proteins actually present at the time of sampling can be distinguished and different forms of the same protein can be resolved. The analysis of proteomes from organisms has been performed extensively by exploring the high resolution of two-dimensional electrophoresis (2DE) coupled with MS. These data, when complemented by de novo sequencing, allow the unequivocal identification of proteins involved in different biological functions. The proteomic approach is a fundamental method by which we can obtain an understanding and identification of the functions of proteins expressed in a given condition.

In this review, we highlight the proteins expressed during plant-virus, plant-bacterium, plant-fungus and plant-nematode interactions reported in proteomic studies, and discuss these findings considering the advantages and limitations of current proteomic tools.

\section{Plant-virus interactions}

For the success of plant infection, viruses must first be transmitted either mechanically or by a vector (transmission), replicate in plant cells (replication), subsequently move through plasmodesmata to neighbouring cells (cell-to-cell movement) and, finally, attain the vascular tissue to circulate systemically through the phloem to 
the sink tissues of the host (vascular movement). After being unloaded from the phloem, viruses establish systemic infection through new cycles of replication and cell-to-cell/vascular movement. In both compatible (susceptible host) and incompatible (resistant host) interactions, viruses use plant host proteins to complete the steps of the infection process and suffer the influences of plant host proteins as a counteraction against the infection. The genes that encode these proteins have been studied extensively in numerous host-virus systems, mainly using transcriptional analysis [4].

Recently, 2DE and subsequent MALDI-TOF MS have been performed to analyse the induced expression of nuclear proteins in Capsicum annuum cv. Bugang (hot pepper) infected by tobacco mosaic tobamovirus (TMV) [5]. C. annuum cv. Bugang is hypersensitive response resistant against $\mathrm{TMV}-\mathrm{P}_{0}$ and susceptible to TMV-P ${ }_{1.2}$ strains. A hypothetical protein and five annotated nuclear proteins (Table 1) were identified in hot pepper infected by $\mathrm{TMV}-\mathrm{P}_{0}$, including four defence-related proteins [14-3-3 protein (regulator of proteins involved in response to biotic stresses), $26 \mathrm{~S}$ proteasome subunit (RPN7) (postulated to be involved in programmed cell death), mRNA-binding protein (may interact with viral RNA or interfere with plant RNA metabolism) and Rab11 GTPase (responsible for membrane trafficking/recycling and endocytosis/ exocytosis)] and a ubiquitin extension protein.
Diaz-Vivancos et al. [6] used proteomic approaches to study the changes in enzymatic activity and protein expression in the antioxidative system within the leaf apoplast of Prunus persica cv. GS305 (peach) on plum pox potyvirus (PPV) infection. PPV infection provoked oxidative stress in peach leaf apoplast by increasing the antioxidant enzymatic activities and $\mathrm{H}_{2} \mathrm{O}_{2}$ contents. 2DE of apoplastic fluids from peach leaves infected with PPV, and subsequent MALDI-TOF MS analyses, revealed the identification of four proteins of the 22 analysed: one thaumatin-like and three mandelonitrile lyases (MDLs) (Table 1). Thaumatins are proteins involved in the plant response against fungal infection, and may equally be expressed in peach as a response to PPV infection [6]. MDLs are flavoproteins involved in the catabolism of $(R)$-amygdaline; however, to define their role in the peach plant-PPV interaction, further investigations must be performed.

Another study on plant-virus interaction was performed by Rahoutei et al. [7,8]. These authors demonstrated that the pepper mild mottle tobamovirus Spanish strain S (PMMoV-S) inhibits photosystem II electron transport, disturbing the oxygen-evolving complex, composed of the three proteins PsbP, PsbO and PsbQ, present within plant thylakoid membranes. PMMoV-S infection results in a lower expression of PsbP and PsbQ in the susceptible host Nicotiana benthamiana Domin (tobacco) relative to that in healthy

Table 1. Proteins expressed in plant-virus interactions and identified in plants using proteomic approaches.

\begin{tabular}{|c|c|c|c|c|}
\hline Protein & $\begin{array}{l}\text { Studied } \\
\text { organism }\end{array}$ & Pathogen & $\begin{array}{l}\text { Accession } \\
\text { no. }^{\text {a }}\end{array}$ & Reference \\
\hline 26S proteasome subunit RPN7 & C. annuum & TMV-Po & DQ975456 & {$[5]$} \\
\hline mRNA-binding protein & C. annuum & TMV-P $\mathrm{P}_{0}$ & Do991047 & {$[5]$} \\
\hline Rab11 GTPase & C. annuum & TMV-P $\mathrm{P}_{0}$ & D0975457 & [5] \\
\hline Ubiquitin extension protein & C. annuum & TMV-P 0 & DQ975458 & [5] \\
\hline 14-3-3 protein & C. annuum & TMV-Po & DQ991045 & [5] \\
\hline Thaumatin-like protein & Prunus persica & PPV & AAM00215 & {$[6]$} \\
\hline $\begin{array}{l}R-(+) \text { mandelonitrile lyase } \\
\text { isoform MDL5 precursor }\end{array}$ & Prunus serotina & PPV & AAC61982 & {$[6]$} \\
\hline $\begin{array}{l}R-(+) \text { mandelonitrile lyase } \\
\text { isoform MDL4 precursor }\end{array}$ & Pr. serotina & PPV & AAD02266 & {$[6]$} \\
\hline Mandelonitrile lyase & Pr. serotina & PPV & CAA51194 & {$[6]$} \\
\hline PsbO (N. benthamiana isoform I) & Pisum sativum & PMMoV-S & P14226 & [9] \\
\hline PsbO (N. benthamiana isoform II) & N. tabacum & PMMoV-S & Q40459 & [9] \\
\hline PsbO ( $N$ benthamiana isoforms III, IV) & $\begin{array}{l}\text { Lycopersicon } \\
\text { esculentum }\end{array}$ & PMMoV-S & P23322 & [9] \\
\hline PsbP (N. benthamiana isoforms $A, B, C)$ & N. tabacum & PMMoV-S & CAA39039 & [9] \\
\hline PsbP (N. benthamiana isoform D) & N. tabacum & PMMoV-S & CAA44292 & [9] \\
\hline Phenylalanine ammonia-lyase & O. sativa & RYMV & P14717 & [11] \\
\hline Mitochondrial chaperonin-60 & O. sativa & RYMV & Q8H903 & [11] \\
\hline Aldolase C-1 & O. sativa & RYMV & Q42476 & [11] \\
\hline
\end{tabular}

a Accession number from the organism of origin. 
control plants. In $N$. benthamiana Domin-PMMoV-S interaction analysis, Perez-Bueno et al. [9] revealed, by 2DE immunoblotting and $\mathrm{N}$-terminal sequencing of proteins from the thylakoid membranes, that there are four isoforms of PsbO and four isoforms of PsbP in $N$. benthamiana Domin (Table 1). These authors also showed that the expression of the four isoforms of PsbP decreases considerably in relation to PsbO proteins as the infection progresses. The fact that damage to the activity of the oxygen-evolving complex in virus-infected plants results in higher viral accumulation in the host may indicate the participation of PsbO in a basal resistance mechanism against viruses and in plant counteraction against the deleterious effects of viruses on photosynthetic activity [10].

Proteomic analysis was also performed to study the compatible interaction between Oryza sativa (rice) and rice yellow mottle sobemovirus (RYMV) [11]. This analysis led to the identification of a phenylalanine ammonia-lyase, a mitochondrial chaperonin-60 and an aldolase $\mathrm{C}$ (Table 1), but the role of these proteins during RYMV infection of rice remains to be determined. In another analysis of the same interaction, Brizard et al. [12] investigated RYMV-rice (susceptible O. sativa indica IR64) protein complexes (formed in vivo or in vitro) to identify plant proteins putatively involved in the virus-host interactions. SDS-PAGE analysis, followed by nano-LC-MS/MS, revealed the presence of 223 different proteins that fitted into three functional categories. In the metabolism category, a large number of enzymes involved in glycolysis, malate and citrate cycles were found, probably recruited by RYMV for the production of energy to support viral replication [12]. In the defence category, proteins involved in the generation and detoxification of reactive oxygen species were identified, presumably to maintain an oxido-reduction environment compatible with viral replication [12]. In the protein synthesis category, proteins involved in translation, elongation factors, chaperones, protein-disulfide isomerases and proteins involved in protein turnover with the $20 \mathrm{~S}$ proteasome were observed [12]. Again these proteins may be recruited by RYMV to optimize the efficiency of viral infectivity [12]. Finally, in a recent proteomic study, the interaction of tomato fruits (Lycopersicon esculentum) with TMV was analysed. Of the 16 proteins identified, there were several pathogenesisrelated (PR) proteins and antioxidant enzymes found to be expressed as a probable part of the plant resistance mechanism against viral infection [13].

Although proteomic approaches have shown the participation of several plant proteins (mentioned above) in virus replication, the involvement of plant factors in viral movement has never been demonstrated through proteomics. As viral movement in plants is tissue specific and involves various cell types which are difficult to isolate, such as leaf parenchyma (where cell-to-cell movement occurs) and phloem (where vascular movement occurs), the performance of proteomic assays of each separate tissue is hampered.

\section{Plant-bacterium interactions}

Bacteria rely on diverse secretion pathways in order to overcome plant defences and to establish successful colonization of the host plant. Five secretion systems (types $\mathrm{I}-\mathrm{V}$ ) have been reported in bacteria, which are distinguished by their constituent proteins [14]. The main secretion system used by pathogenic bacteria during infection is the type III secretion system (TTSS), which is involved in some of the most devastating diseases in animals and plants (for a review, see [15]). This system enables bacteria to directly inject proteins, called effectors or virulence factors, into the host cell and subvert cellular processes. TTSS is essential for pathogenicity and is conserved amongst Gram-negative bacteria; however, the proteins exported by this system are more variable $[16,17]$. The best-studied TTSS effectors are designated avirulence (Avr) proteins, which have been reported in several plant pathogens [18-21]. Other effectors have also been identified in different phytopathogenic bacterial species, including Xanthomonas outer protein (Xop) in Xanthomonas [22], Hrp outer protein (Hop) in Pseudomonas [23] and Pseudomonas outer protein (Pop) (based on a previous genus designation) in Ralstonia [24].

Another important system for bacterial pathogenicity is the type II secretion system, which is involved in the secretion of extracellular enzymes, toxins and virulence factors. Striking differences in the number and combinations of these enzymes in different pathogens are expected to be found.

Most of the data currently available on pathogenicity mechanisms in bacteria have been obtained by genomic studies. Few studies have employed the proteomic approach, which aims to identify the bacterial proteins putatively involved in pathogenicity. Mehta and Rosato [25] reported the analysis of Xanthomonas axonopodis pv. citri cultivated in the presence of the host Citrus sinensis leaf extract, and identified differentially expressed proteins, including a sulfate-binding protein, by $\mathrm{NH}_{2}$ terminal sequencing (Table 2). The authors suggested that the induction of this enzyme may have been caused by the amino acids or different sugars present in the leaf extract. Tahara et al. [26] analysed the expressed proteins of $X$. axonopodis pv. passiflorae 
Table 2. Proteins identified in phytopathogenic bacteria using proteomic approaches.

\begin{tabular}{|c|c|c|c|c|}
\hline Protein & Studied organism & Plant/condition & $\begin{array}{l}\text { Accession } \\
\text { no. }^{\text {a }}\end{array}$ & Reference \\
\hline Sulfate-binding protein & X. axonopodis pv. citri & Citrus sinensis (leaf extract) & PO2906 & [25] \\
\hline Inorganic pyrophosphatase & X. axonopodis pv. passiflorae & Passiflorae edulis (leaf extract) & AAM38285.1 & [26] \\
\hline Outer membrane protein & X. axonopodis pv. passiflorae & Pa. edulis (leaf extract) & AAM38389.1 & [26] \\
\hline $\begin{array}{l}\text { Outer membrane } \\
\text { protein A (OmpA) }\end{array}$ & $\begin{array}{l}\text { Dickeya dadantii } \\
\text { (syn. E. chrysanthemı) }\end{array}$ & $\begin{array}{l}\text { Saintpaulia ionantha } \\
\text { (leaf extract) }\end{array}$ & 18822 & [27] \\
\hline $\begin{array}{l}\text { Type III secretory pathway, } \\
\text { porin component }(\mathrm{HrcC})\end{array}$ & D. dadantii (syn. E. chrysanthemı) & Sa. ionantha (leaf extract) & 20864 & {$[27]$} \\
\hline $\begin{array}{l}\text { Oligogalacturonate } \\
\text { specific porin (KdgN) }\end{array}$ & D. dadantii (syn. E. chrysanthemı) & Sa. ionantha (leaf extract) & 15523 & [27] \\
\hline $\begin{array}{l}\text { Oligogalacturonate } \\
\text { specific porin (KdgM) }\end{array}$ & D. dadantii (syn. E. chrysanthemi) & Sa. ionantha (leaf extract) & 19629 & [27] \\
\hline Polygalacturonase X (pehX) & E. chrysanthemi & $\begin{array}{l}\text { Chrysanthemum leaves } \\
\text { (leaf extract) }\end{array}$ & 14958 & [31] \\
\hline Avr-like protein & E. chrysanthemi & $\begin{array}{l}\text { Chrysanthemum leaves } \\
\text { (leaf extract) }\end{array}$ & 19143 & [31] \\
\hline Metalloprotease A & E. chrysanthemi & $\begin{array}{l}\text { Chrysanthemum leaves } \\
\text { (leaf extract) }\end{array}$ & 20373 & [31] \\
\hline Cellulase & E. chrysanthemi & $\begin{array}{l}\text { Chrysanthemum leaves } \\
\text { (leaf extract) }\end{array}$ & 18772 & [31] \\
\hline OmpA-related protein & X. campestris pv. campestris & Culture media & AAM42288 & [32] \\
\hline Cellulase & X. campestris pv. campestris & Culture media & AAM42791 & [32] \\
\hline Superoxide dismutase & X. campestris pv. campestris & Culture media & AAM41557 & [32] \\
\hline $\begin{array}{l}\text { Arabinogalactan } \\
\text { endo-1,4- } \beta \text {-galactosidase }\end{array}$ & X. campestris pv. campestris & Culture media & AAM42894 & [32] \\
\hline GroEL (60 kDa chaperonin) & X. campestris pv. campestris & Culture media & AAM39839 & [32] \\
\hline
\end{tabular}

${ }^{a}$ Accession number from the organism of origin.

during the interaction with the host Passiflorae edulis leaf extract, and identified an inorganic pyrophosphatase and an outer membrane protein upregulated in the presence of leaf extract, also by $\mathrm{NH}_{2}$ terminal sequencing. It was proposed that the outer membrane protein identified may have an important role in pathogenicity [26].

Plant extracts have also been used as a stress condition in the analysis of outer membrane proteins of the soft rot pathogen Dickeya dadantii (syn. Erwinia chrysanthemi) by 2DE and MALDI-TOF MS analyses [27]. Several proteins were identified, such as the porin OmpA, involved in binding to specific host cell receptor molecules [27], HrcC, a member of the PulD/pIV superfamily of proteins that function in outer membrane translocation of type II and type III secretion pathways [28], and the oligogalacturonate-0 specific porins $\mathrm{KdgM}$ and $\mathrm{KdgN}$ [27].

The E. chrysanthemi proteome was further analysed by comparing E. chrysanthemi wild-type and osmoregulated periplasmic glucan (OPG)-defective mutant cells, which show a loss of virulence, by 2DE. Several proteins differentially expressed in the mutant cells, essential for cellular processes such as protein folding and degradation and carbohydrate metabolism, were identified [29]. The authors concluded that E. chrysanthemi responds to OPG deficiency by activating cellular processes that protect the cell against environmental stresses, which suggests that the opgG strain is impaired in the perception of its environment [29].

In a 2DE-mediated proteomic study of Xylella fastidi$o s a$, the causal agent of citrus variegated chlorosis, it was observed that $X$. fastidiosa did not produce significant changes in heat shock protein expression when compared with $X$. axonopodis pv. citri [30]. However, it was found that $X$. fastidiosa constitutively expressed several stress-inducible proteins, such as HspA and GroeS, which were induced in $X$. citri under stress conditions. The authors suggested that the constitutive expression of these proteins may help $X$. fastidiosa cope with sudden environmental changes and stresses.

Secretome analysis is a primary field of study of bacterial pathogenicity, which may reveal new virulence proteins. As a result of the high importance of secreted proteins in the bacterial infection process, the E. chrysanthemi secretome was analysed and revealed an upregulation of several pectate lyases expressed in the presence of leaf extract of Chrysanthemum [31]. These enzymes play a crucial role in E. chrysanthemi infection, and the occurrence of several isoforms may 
permit pathogenicity to a variety of different conditions and hosts [31]. A polygalacturonase $\mathrm{X}$, which is another cell wall-degrading enzyme (CWDE), was also identified using MALDI-TOF analysis [31]. Similarly, several secreted proteins involved in various functions were identified in the Xanthomonas secretome [32], including outer membrane proteins, proteins involved in trace element acquisition, degrading enzymes, metabolic enzymes, proteins involved in maintenance and folding, and proteins with other functions (Table 2).

Other proteomic studies have reported global protein expression and reference maps of important bacterial plant pathogens, including X. fastidiosa [33] and Agrobacterium tumefaciens [34]; however, proteomic studies of the direct interaction of these pathogens with the plant or plant extracts are still at an initial stage.

With regard to plant defence responses, direct evidence of the involvement of target proteins has also been provided by proteomic studies. Although few, the reports outlined below clearly show the importance of proteomic approaches, which can aid significantly in the understanding of plant-bacterium interactions. Jones et al. [3], in the same study, analysed the proteomic and transcriptomic profiles of Arabidopsis thaliana leaves during early responses (1-6 $\mathrm{h}$ postinoculation) to the challenge by Pseudomonas syringae pv. tomato. They compared the proteomic changes in A. thaliana in response to the $P$. syringae pv. tomato highly virulent strain DC3000, which results in successful parasitism, a DC3000 hrp mutant, which induces basal resistance, and a transconjugant of DC3000 expressing avrRpml, which triggers a gene-for-gene-based resistance. Two subsets of proteins, which consistently showed clear differences in abundance after various challenges and time intervals, were glutathione $S$-transferases (GSTs) and peroxiredoxins (Prxs). Both of these groups of antioxidant enzymes were considered to have probable significant roles in the regulation

Table 3. Proteins expressed in plant-bacterium interactions and identified in plants using proteomic approaches.

\begin{tabular}{|c|c|c|c|c|}
\hline Protein & $\begin{array}{l}\text { Studied } \\
\text { organism }\end{array}$ & Pathogen & $\begin{array}{l}\text { Accession } \\
\text { no. }^{\text {a }}\end{array}$ & Reference \\
\hline Glutathione $S$-transferase & A. thaliana & P. syringae & $\begin{array}{l}\text { At2g47730 } \\
\text { At4g02520 } \\
\text { At1g02930 } \\
\text { At1g02920 }\end{array}$ & {$[3,35]$} \\
\hline Peroxiredoxin & A. thaliana & P. syringae & $\begin{array}{l}\text { At5g06290 } \\
\text { At3g52960 } \\
\text { At3g11630 }\end{array}$ & {$[3,35]$} \\
\hline Peroxiredoxin, chloroplast & O. sativa & X. oryzae pv. oryzae & AM039889 & {$[36]$} \\
\hline $\begin{array}{l}\text { Glyceraldehyde 3-phosphate } \\
\text { dehydrogenase }\end{array}$ & O. sativa & X. oryzae pv. oryzae & S33872 & [36] \\
\hline $\begin{array}{l}\text { Triosephosphate isomerase, cytosolic } \\
\text { (EC 5.3.1.1) }\end{array}$ & O. sativa & X. oryzae pv. oryzae & P46226 & [36] \\
\hline Thaumatin-like protein & O. sativa & X. oryzae pv. oryzae & P31110 & [36] \\
\hline Superoxide dismutase & O. sativa & $X$. oryzae pv. oryzae & S29146 & {$[36]$} \\
\hline Alcohol dehydrogenase 1 & O. sativa & X. oryzae pv. oryzae & CAA34363 & [37] \\
\hline Quinone reductase & O. sativa & $X$. oryzae pv. oryzae & NP_916411 & [37] \\
\hline Prohibitin & O. sativa & X. oryzae pv. oryzae & NP_916591 & [37] \\
\hline Hypersensitive-induced response & O. sativa & X. oryzae pv. oryzae & AAK54610 & [37] \\
\hline Ascorbate peroxidase & O. sativa & X. oryzae pv. oryzae & $X P \_470658$ & [37] \\
\hline Zinc finger and $\mathrm{C} 2$ domain protein-like & O. sativa & X. oryzae pv. oryzae & XP_478243 & [37] \\
\hline Low molecular weight heat shock protein & O. sativa & X. oryzae pv. oryzae & NP_912354 & [37] \\
\hline Universal Stress Protein & O. sativa & $X$. oryzae pv. oryzae & AAP53941 & [37] \\
\hline Remorin 1 & $\begin{array}{l}\text { Lycopersicon } \\
\text { hirsutum }\end{array}$ & $\begin{array}{l}\text { Clavibacter michiganensis ssp. } \\
\text { michiganensis }\end{array}$ & 4731573 & [38] \\
\hline $\begin{array}{l}\text { Phospholipid hydroperoxide } \\
\text { glutathione peroxidase }\end{array}$ & L. hirsutum & $\begin{array}{l}\text { Cl. michiganensis ssp. } \\
\text { michiganensis }\end{array}$ & 31872080 & [38] \\
\hline $\begin{array}{l}\text { Pathogenesis-related } 3 \\
\text { (endochitinase precursor) }\end{array}$ & L. hirsutum & $\begin{array}{l}\text { Cl. michiganensis ssp. } \\
\text { michiganensis }\end{array}$ & Q05540 & [38] \\
\hline Glutathione $S$-transferase & L. hirsutum & $\begin{array}{l}\text { Cl. michiganensis ssp. } \\
\text { michiganensis }\end{array}$ & TC116034 & [38] \\
\hline Ascorbate peroxidase & L. hirsutum & $\begin{array}{l}\text { Cl. michiganensis ssp. } \\
\text { michiganensis }\end{array}$ & 6066418 & [38] \\
\hline
\end{tabular}

${ }^{a}$ Accession number from the organism of origin. 
of redox conditions within infected tissue (Table 3). These results were further related to changes in the expression profiles for the corresponding GST and Prx genes, identified by Affymetrix GeneChip analysis. In general, a good correlation was observed between changes obtained at the transcript and protein levels for the Prx family, but not for the GST family. Only for the PrxB protein was the decrease observed in the spot intensity following pathogen challenge clearly related to transcriptional suppression. These observations were used to highlight the complexity of comparative proteomics and transcriptomics, even when derived from the same inoculation system.

As a follow-up study, the same group [35] examined the global proteomic profile in three subcellular fractions (soluble protein, chloroplast- and mitochondriaenriched) of $A$. thaliana responding to the same three $P$. syringae pv. tomato DC3000 strains. This was the first report to associate post-translational events $(1-6 \mathrm{~h}$ postinoculation) occurring before significant transcriptional reprogramming. In total, 73 differential spots representing 52 unique proteins were successfully identified, and were representative of two major functional groups: defence-related antioxidants and metabolic enzymes. The results show that several chloroplast systems are modified during all aspects of the defence response. Components of the Calvin-Benson cycle are rapidly altered during basal defence, and some of these changes are reversed by type III effectors. Photosystem II has emerged as a target of resistance signalling. Mitochondrial porins appear to be modified early in basal defence, with specific alterations to other components in response to AvrRpm1. Finally, the interplay between redox status and glycolysis, with probable links to lipid signalling [through glyceraldehyde 3-phosphate dehydrogenase, some GSTs, lipase and NADH: quinone oxidoreductase $(\mathrm{NQR})]$, may coordinate communication between organelles. Significant changes to photosystem II and to mitochondrial porins seem to occur early in basal defence. Rapid communication between organelles and the regulation of primary metabolism through redoxmediated signalling are supported by these results.

To investigate the role of defence-responsive proteins in the rice-Xanthomonas oryzae pv. oryzae interaction, Mahmood et al. [36] applied a proteomic approach. Cytosolic and membrane proteins were fractionated from the rice leaf blades 3 days postinoculation with incompatible and compatible $X$. oryzae pv. oryzae races. From 366 proteins analysed by $2 \mathrm{DE}, 20$ were differentially expressed in response to bacterial inoculation (Table 3). Analyses clearly revealed that four defence-related proteins [PR-5, probenazole-inducible protein (PBZ1), SOD and Prx] were induced for both compatible and incompatible $X$. oryzae pv. oryzae races, wherein PR-5 and PBZ1 were more rapid and showed higher induction in incompatible interactions and in the presence of jasmonic acid.

Studying the same rice- $X$. oryzae pv. oryzae interaction, Chen et al. [37] analysed proteins from rice plasma membrane to study the early defence responses involved in XA21-mediated resistance. XA21 is a rice receptor kinase, predicted to perceive the $X$. oryzae pv. oryzae signal at the cell surface, leading to the 'gene-for-gene' resistance response. They observed a total of 20 proteins differentially regulated by pathogen challenge at 12 and $24 \mathrm{~h}$ postinoculation, and identified at least eight putative plasma membrane-associated and two non-plasma membrane-associated proteins (Table 2) with potential functions in rice defence.

Proteins from the wild tomato species Lycopersicon hirsutum that are regulated in response to the causal agent of bacterial canker (Clavibacter michiganensis ssp. michiganensis) were identified by comparing two partially resistant lines and a susceptible control line in a time course (72 and $144 \mathrm{~h}$ postinoculation) experiment [38]. Using 2DE and ESI-MS/MS, 26 differentially regulated tomato proteins were identified, 12 of which were directly related to defence and stress responses (Table 3).

Proteomic analysis was also used to detect the responses of the model legume Medicago truncatula to the pathogenic bacterium Pseudomonas aeruginosa in the presence of known bacterial quorum-sensing signals, such as $N$-acyl homoserine lactone (AHL) [39]. The fast and reliable detection of bacterial AHL signals by plant hosts is essential to make appropriate responses to the pathogen. Therefore, M. truncatula is able to detect very low concentrations of AHL from $P$. aeruginosa, and responds in a global manner by significant changes in the accumulation of 154 proteins, 21 of which are related to defence and stress responses.

As phosphorylation plays a central role in the initiation of the plant response to bacterial signals, phosphoproteomics (large-scale analysis of phosphoproteins) is a powerful strategy to better understand the events that occur rapidly in the host after bacterial perception [40]. Although it has been shown that the phosphorylation pathway of proteins changes rapidly after signal perception, relatively few of these phosphoproteins have been identified in plant species. By using a phosphoproteome approach, early changes in proteins potentially phosphorylated during the bacterial defence response have been described, and include dehydrin, chaperone, heat shock protein and glucanase $[41,42]$. The phosphorylation of these proteins is probably part of the early basal plant defence response. 


\section{Plant-fungus interactions}

Considerable advances have been achieved in the last 10 years in the identification of the determinants of plant-fungus interactions. Currently, more than 25 fungal genomes have been elucidated, including human and plant pathogens, such as Aspergillus fumigatus and Magnaporthe grisea, respectively (http://www.broad. mit.edu/annotation/fgi/). A key challenge in modern fungal biology is to analyse the expression, function and regulation of the entire set of proteins encoded by the revealed fungal genomes.

When pathogenic fungi start the infection process, secreted and intracellular proteins are up- or downregulated, improving the predation ability of fungi $[43,44]$. In this field, several proteomic studies have been carried out in order to understand fungal pathogenicity. These include pioneering studies, aimed at an understanding of the dimorphic transition from budding to filamentous growth [45] as well as appressorium construction [46]. Appressorium formation is believed to be an important event in the establishment of a successful interaction between the pathogen Phytophtora infestans and its host plant potato [46]. Although most spots were not identified, some proteins involved in amino acid biosynthesis, including methionine and threonine synthases, were obtained (Table 4).

Proteomic analyses have also been used to study wheat leaf rust, caused by the fungus Puccinia triticina [47]. Rust diseases cause a significant annual decrease in the yield of cereal crops worldwide [48]. In order to better understand this problem at the molecular level, the proteomes of both host and pathogen were evaluated during disease development. A susceptible line of wheat infected with a virulent race of leaf rust was compared with mock-inoculated wheat using 2DE (with isoelectric focusing, $\mathrm{pH} \mathrm{4-8)} \mathrm{and} \mathrm{MS} \mathrm{analysis}$ [47]. The fungus differentially expressed 22 different proteins during pathogen infection, including proteins with known and hypothetical functions.

Another approach, which has been frequently employed for the study of fungal proteins, involves the analysis of the exoproteome, also known as the secretome [49]. In this context, Fusarium graminearum, a devastating pathogen of wheat, maize and other cereals, was grown on hop (Humulus lupulus) cell walls. Using $1 \mathrm{DE}$ and 2DE, followed by MS analyses, 84 fungal secreted proteins were identified [49]. Amongst the identified proteins were cellulases, glucanosyltransferases, endoglucanases, phospholipases, proteinases and chitinases (Table 4). It was observed that $45 \%$ of the proteins observed in F. graminearum grown in the presence of hop cells were strictly involved in cell wall degradation and indirectly related to carbon and nitrogen absorption. When this same fungus was grown in a medium containing glucose, however, the enzyme patterns were totally different, showing that fungi are capable of regulating their secretion according to the presence of substrate [49].

A cell wall proteome was also proposed for Phytophthora ramorum, the causal agent of sudden oak death [50]. This study showed an inventory of cell wall-associated proteins based on MS sequence analysis. Seventeen proteins were identified, all of which were authentic secretory proteins. Functional classification based on homology searches revealed six putative mucins, five putative glycoside hydrolases, two transglutaminases, one annexin-like protein and one Kazal-type protease inhibitor [50], clearly suggesting that cell wall proteins are also important for fungal pathogenicity (Table 4).

Another fungal exoproteome was analysed in order to gain a more thorough understanding of the phytopathogenic fungus Sclerotinia sclerotiorum [51]. Extracted secreted proteins collected from liquid culture were separated using 2DE and annotated following ESI-Q-TOF MS/MS. Fifty-two secreted proteins were identified by MALDI-MS/MS peptide sequencing, and many of the annotated secreted proteins were cell wall-degrading enzymes that had been identified previously as pathogenicity or virulence factors of S. sclerotiorum. However, one of the identified proteins, $\alpha$-L-arabinofuranosidase, which is involved in the virulence process of S. sclerotiorum, was not detected by EST studies, clearly demonstrating the merit of performing proteome-level research [51].

With regard to plant responses, although only a few proteomic studies have focused on plant-pathogen interactions, the plant-fungus association has been the most studied using this approach. In such studies, several proteins involved in diverse biological processes, including defence and stress responses, signal transduction, photosynthesis, electron transport and metabolism, have been found. Some examples reporting these proteins are mentioned below.

The Ma. grisea-rice interaction is a model system for understanding plant disease because of its great economic importance, and also because of the genetic and molecular genetic tractability of the fungus [52]. What makes this an important system is that both genomes have been sequenced and a rice proteome database is available (http://gene64.dna.affrc.go.jp/ $\mathrm{RPD} /$ main.html). A pioneering study on rice proteomics was performed to analyse the protein profile after 
Table 4. Proteins identified in phytopathogenic fungi using proteomic approaches.

\begin{tabular}{|c|c|c|c|c|}
\hline Protein & Studied organism & Plant/condition & Accession no. ${ }^{a}$ & Reference \\
\hline $\begin{array}{l}\text { Methionine synthase } \\
\text { (Pi-met1) gene }\end{array}$ & Phytophtora infestans & Solanum tuberosum & NP_660391 & [46] \\
\hline Threonine synthase & Ph. infestans & So. tuberosum & 8439546 & {$[46]$} \\
\hline Chitinase & F. graminearum & Humulus lupulus & - & [49] \\
\hline Serine proteinase & F. graminearum & Hu. Iupulus & - & [49] \\
\hline Leucine aminopeptidase & F. graminearum & Hu. Iupulus & - & [49] \\
\hline Lipases & F. graminearum & Hu. Iupulus & - & [49] \\
\hline Pectate lyase & F. graminearum & Hu. Iupulus & - & [49] \\
\hline$\alpha$-Arabinofuranidase & F. graminearum & Hu. Iupulus & - & [49] \\
\hline Ceramidase & F. graminearum & Hu. lupulus & - & [49] \\
\hline Chitin deacetylase & F. graminearum & Hu. Iupulus & - & [49] \\
\hline$\beta$-Glucosidase & F. graminearum & Hu. Iupulus & - & [49] \\
\hline Polygalacturonidase & F. graminearum & Hu. Iupulus & - & [49] \\
\hline Trypsin & F. graminearum & Hu. Iupulus & - & [49] \\
\hline Aspartyl proteinase & F. graminearum & Hu. Iupulus & - & [49] \\
\hline Xyloglucanase & F. graminearum & Hu. Iupulus & - & [49] \\
\hline Carboxypeptidase & F. graminearum & Hu. Iupulus & - & [49] \\
\hline$\alpha$-Amylase & F. graminearum & Hu. Iupulus & v & [49] \\
\hline Mucin & Ph. ramorum & Oak & 73547 & {$[50]$} \\
\hline \multirow[t]{4}{*}{ Glucanase } & Ph. ramorum & Oak & $74257 a$ & {$[50]$} \\
\hline & & & $74257 b$ & \\
\hline & & & 72319 & \\
\hline & & & 83680 & \\
\hline \multirow[t]{2}{*}{ Transglutaminases } & Ph. ramorum & Oak & 53744 & {$[50]$} \\
\hline & & & 83169 & \\
\hline \multirow[t]{3}{*}{ Exopolygalacturonase } & S. sclerotiorum & Culture media & gi32454433 & [51] \\
\hline & & & gi1483221 & \\
\hline & & & gi2196886 & \\
\hline $\begin{array}{l}\text { Cellobiohydrolase } 1 \text { catalytic } \\
\text { domain }\end{array}$ & S. sclerotiorum & Culture media & gi20986705 & [51] \\
\hline Acid protease & S. sclerotiorum & Culture media & gi6984107 & {$[51]$} \\
\hline $\begin{array}{l}\text { Aspartic proteinase precursor: } \\
\text { aspartyl proteinase }\end{array}$ & S. sclerotiorum & Culture media & gi12002205 & [51] \\
\hline
\end{tabular}

a Accession number from the organism of origin.

Ma. grisea infection, and was conducted using infected leaf blades fertilized with various levels of nitrogen [53]. Rice plants grown with high levels of nitrogen nutrient are more susceptible to infection by the blast fungus [54]. Although this study failed to establish any correlation between nitrogen application and disease resistance, leaf proteins revealed some minor changes when plants grown under different levels of nitrogen were compared [55]. Twelve proteins, including the rice thaumatin-like protein (TLP) (PR-5), were identified with accumulation changes at different levels of nitrogen.

Another study of the same interaction was performed by Kim et al. [56] using rice suspensioncultured cells. Twelve proteins from six different genes were identified, including the rice pathogenesis-related protein class 10 (OsPR-10), isoflavone reductase-like protein (PBZ1), glucosidase and putative receptor-like protein kinase (RLK), which had not been reported previously in suspension-cultured rice cells (Table 5). The authors followed with another proteome study using rice leaves, where they identified eight proteins newly induced or with increased expression [57]. The identified proteins belonged to several groups of PR proteins, and included two RLKs, two $\beta$-1,3-glucanases (Glu1, Glu2), TLP, peroxidase (POX 22.3), PBZ1 and OsPR-10 (Table 5). Although the proteins identified by Kim et al. [56,57] are most probably involved in the plant response to fungal attack and plant resistance/susceptibility, the purpose and function of each was not investigated in these preliminary and exploratory studies.

Another rice-fungus interaction study reported recently was that of sheath blight, caused by the fungus Rhizoctonia solani. Lee et al. [58] investigated rice sheath leaves after infection with this fungus, and the 
Table 5. Proteins expressed in plant-fungus interactions and identified in plants using proteomic approaches.

\begin{tabular}{|c|c|c|c|c|}
\hline Protein & Studied organism & Pathogen & Accession no. ${ }^{a}$ & Reference \\
\hline \multirow[t]{5}{*}{ Peroxidases (PR-9) } & O. sativa & Ma. grisea & AAC49818 & [57] \\
\hline & O. sativa & Rhizoctonia solani & gi32879781 & [58] \\
\hline & Triticum aestivum & F. graminearum & AAL08496 & [59] \\
\hline & Tomato & F. oxysporum & - & {$[62]$} \\
\hline & A. thaliana & Fusarium elicitor & At1g07890 & [75] \\
\hline \multirow[t]{5}{*}{ B-1,3-Glucanases (PR-2) } & O. sativa & Ma. grisea & BBA77783 & [57] \\
\hline & O. sativa & R. solani & gi4884530 & [58] \\
\hline & T. aestivum & F. graminearum & AAD28734 & [59] \\
\hline & Zea mays & F. verticillioides & - & [61] \\
\hline & Tomato & F. oxysporum & AAA03617 & [62] \\
\hline \multirow[t]{4}{*}{ Thaumatin-like protein (PR-5) } & O. sativa & Ma. grisea & - & [53] \\
\hline & O. sativa & Ma. grisea & T04165 & [57] \\
\hline & T. aestivum & F. graminearum & CAA66278 & [59] \\
\hline & Tomato & F. oxysporum & AAM23272 & {$[62]$} \\
\hline \multirow[t]{3}{*}{ Chitinase (PR-3) } & O. sativa & R. solani & gi55168113 & [58] \\
\hline & T. aestivum & F. graminearum & BAB82472 & [59] \\
\hline & Tomato & F. oxysporum & CAA78845 & [62] \\
\hline \multirow[t]{3}{*}{ Glutathione S-transferase } & T. aestivum & F. graminearum & CAC94005 & [59] \\
\hline & Z. mays & F. verticillioides & 2288968 & {$[61]$} \\
\hline & A. thaliana & Fusarium elicitor & At1g02930 & {$[75]$} \\
\hline \multirow{3}{*}{$\begin{array}{l}\text { Glyceraldehyde 3-phosphate } \\
\text { dehydrogenase }\end{array}$} & O. sativa & R. solani & gi166702 & [58] \\
\hline & T. aestivum & F. graminearum & XP493811 & [59] \\
\hline & Z. mays & F. verticillioides & Q09054 & {$[61]$} \\
\hline \multirow[t]{3}{*}{ Pathogenesis-related class 10} & O. sativa & Ma. grisea & T14817 & {$[56]$} \\
\hline & O. sativa & Ma. grisea & AF416604 & {$[57]$} \\
\hline & M. truncatula & $\begin{array}{l}\text { Aphanomuces } \\
\text { euteiches }\end{array}$ & P93333 & {$[60]$} \\
\hline \multirow[t]{2}{*}{ Fructose-bisphosphate aldolase } & Z. mays & F. verticillioides & P08440 & [61] \\
\hline & A. thaliana & Fungal elicitor & At3g52930 & [75] \\
\hline \multirow[t]{2}{*}{ Probenazole-induced protein } & O. sativa & Ma. grisea & T02973 & {$[56]$} \\
\hline & O. sativa & Ma. grisea & T02973 & [57] \\
\hline Adenosine kinase & Z. mays & F. verticillioides & AJ012281 & {$[61]$} \\
\hline Superoxide dismutase (Cu-Zn) & Z. mays & F. verticillioides & P23346 & {$[61]$} \\
\hline Glutamate dehydrogenase & T. aestivum & F. graminearum & AAB51596 & [59] \\
\hline Thioredoxin & T. aestivum & F. graminearum & CAA06735 & [59] \\
\hline $\begin{array}{l}\text { Disease-resistance-response } \\
\text { protein pi } 49\end{array}$ & M. truncatula & $\begin{array}{l}\text { Aphanomuces } \\
\text { euteiches }\end{array}$ & PI4710 & {$[60]$} \\
\hline $20 S$ proteasome $\beta$ unit & O. sativa & R. solani & gi50933089 & [58] \\
\hline Chaperonin $60 \beta$ percursor & O. sativa & R. solani & gi34897924 & [58] \\
\hline \multirow[t]{2}{*}{ Receptor-like protein kinase } & O. sativa & Ma. grisea & & {$[56]$} \\
\hline & O. sativa & Ma. grisea & AAL87185 & [57] \\
\hline 14-3-3-like protein & O. sativa & R. solani & gi7271253 & [58] \\
\hline
\end{tabular}

${ }^{a}$ Accession number from the organism of origin.

results revealed six proteins whose relative abundance varied significantly in the resistant and susceptible lines, and 11 additional proteins which were identified in abundance in the response of the resistant line only. These proteins have been reported previously to be involved in antifungal activity, signal transduction, energy metabolism, photosynthesis, protein folding and degradation, and antioxidation (Table 5), indicating a common pathway for both stress and non-stress plant functions.
Many other efforts have focused on the plant response to fungal attack. Fusarium head blight, caused mainly by $F$. graminearum, is one of the most destructive diseases of wheat, and the interaction between them has been investigated [59]. Zhou et al. [59] found 33 plant proteins which were expressed in response to $F$. graminearum in wheat spikes (Table 5). These proteins were divided into two groups, each related to defence response or metabolism. The authors suggested that several of these proteins were 
Table 6. Proteins expressed in plant-parasitic nematode species identified by proteomic approaches.

\begin{tabular}{|c|c|c|c|}
\hline Protein & Studied organism & Accession no. ${ }^{a}$ & Reference \\
\hline$\beta$-1,4-endoglucanase 2 precursor & H. schachtii & AJ299387 & [69] \\
\hline No known homologue & H. schachtii & - & [69] \\
\hline Calreticulin precursor & MI. incognita & - & [70] \\
\hline Tropomyosin & MI. incognita & - & [70] \\
\hline Myosin regulatory light chain 2 & MI. incognita & - & {$[70]$} \\
\hline ATP synthase $\beta$ chain & MI. incognita & - & [70] \\
\hline Chaperonin protein HSP-60 & $\begin{array}{l}\text { MI. arenaria- } \\
\text { Ml. javanica-Meloidogyne sp. }\end{array}$ & AAA28077 & [71] \\
\hline Actin protein 4 , isoform $\mathrm{c}$ & $\begin{array}{l}\text { MI. arenaria- } \\
\text { MI. javanica-Meloidogyne sp. }\end{array}$ & Q8I9k0 & [71] \\
\hline Translation initiation factor elF-4A & MI. incognita & S26281 & [71] \\
\hline Enolase & MI. incognita & Q8MU59 & [71] \\
\hline
\end{tabular}

${ }^{\text {a }}$ Accession number from the organism of origin.

directly involved in mounting the plant defence against infection by protecting against the oxidative burst inside the plant cell. Such a burst can be caused in plant cells by invading fungus.

Although most reports have focused on the leaf proteome, some studies have also analysed other tissues and organs. Using $2 \mathrm{DE}$, the root protein profiles of M. truncatula were analysed after Aphanomyces euteiches pathogen infection during a time course experiment [60]. The majority of the induced proteins belonged to the PR-10 family, whereas others corresponded to putative cell wall proteins and enzymes of the phenylpropanoid-isoflavonoid pathway (Table 5). Another study focused on Zea mays embryos in response to the fungus Fusarium verticillioides [61]. The proteins identified included PR proteins, antioxidant enzymes and proteins involved in protein synthesis, folding and stabilization.

Another interesting study was performed to investigate the molecular details of the interaction between the xylem-colonizing plant-pathogenic fungus Fusarium oxysporum and tomato [62]. The composition of the xylem sap proteome of infected tomato plants was investigated and compared with that of healthy plants. Two-dimensional gel separation and MS identified 33 different proteins. Sixteen tomato proteins were found in the xylem sap for the first time. Amongst these proteins were peroxidases, chitinases, polygalacturonase and a subtilisin-like protease. It should be noted that these induced proteins are involved in cell wall, cell structure and antioxidant protection.

\section{Plant-nematode interactions}

Plants are continuously attacked by phytonematodes, which cause severe damage in susceptible agricultural crops, resulting in extensive economic losses worldwide [63]. Some of the most harmful plant-parasitic nematodes include the obligate sedentary endoparasites Meloidogyne spp., Heterodera spp. and Globodera spp. [63]. These organisms invade plant roots as juvenile larvae (J2) and, after three moults, develop into adult forms that reproduce in repeated cycles. This leads to severe modifications in the root system, which cause significant reductions in nutrient and water uptake and plant death [64].

In recent years, several nematode expressed sequence tag (EST) libraries have been constructed, mainly to identify parasitic nematode-specific genes, and approximately 100000 ESTs have been sequenced from Meloidogyne, Globodera and Heterodera species (http:// www.nematode.net). Despite the large number of ESTs, only a few of these genes are known to be involved in parasitism, although many of the transcripts are differentially expressed during parasitic stages [65-68]. Proteomic approaches have also contributed to the identification of candidates for the phytonematode parasitome, although to a lesser extent [69-71]. Some of these identified nematode proteins are highlighted in Table 6, and are involved in feeding site and cell wall degradation.

Despite the few proteomic studies, 2DE allied to MS is a powerful and rapid strategy to generate peptide sequence tags that can be linked to ESTs in silico. These peptides can be further used to design primers in order to obtain full-length gene sequences, contributing to parasitic genome projects [72]. In spite of the large amount of experimental and in silico evidence, few studies have aimed to determine the real importance of these sequences in plant-nematode interactions. In addition, EST libraries obtained by the micro-aspiration of cytoplasmic material from the oesophageal glands of 
Meloidogyne incognita and Heterodera glycines reveal that the majority of the genes expressed in these salivary glands encode proteins with unknown function (Ml. incognita, 89\%; H. glycines, 72\%) [66,67].

Considering the other side of the plant-nematode interaction, some plants have evolved protective mechanisms to prevent nematode attraction, penetration, migration, feeding site formation, nourishment by digestion, reproduction and survival. Several resistance genes have been isolated in various plants [73]; however, studies on the proteome of the plant-nematode interaction are at an early stage. In a recent study, three proteins expressed in response to nematode infection have been reported using the proteomic approach, including a chitinase and a PR protein in Coffea canephora and a quinone reductase 2 in Gossipium hirsutum [74].

\section{Understanding plant-pathogen interactions in the light of proteomic studies}

In this review, we have presented the recent proteomic studies performed to better understand plant-virus, plant-bacterium, plant-fungus and plant-nematode interactions. Taken together, the data available reveal that several proteins are commonly expressed in diverse pathosystems (Fig. 1).
In the case of pathogens, several of the proteins involved in pathogenicity are secretion proteins, which were observed in bacteria, fungi and nematodes, and were mainly identified by secretomic studies. These proteins include proteases, cellulases and pectate lyases, which are important CWDEs, crucial for host plant colonization (Fig. 1). These results clearly show the importance of secretomic studies when searching for pathogenicity proteins. In addition to these well-known enzymes, other proteins, such as SODs and oxidases, have also been reported in the different pathogens, and are associated with protection against the oxidative stress response by the plant on infection.

A similar scenario was observed with regard to defence-related proteins in plants. The most reported defence-related proteins are PR proteins, including thaumatins, glucanases, peroxidases and chitinases, observed in several pathosystems described here (Fig. 1). The involvement of these proteins in plant defence has been well established; however, their direct role in resistance enhancement still needs to be demonstrated. The general biotic stress response represents another class of regulated proteins, which include GST, SOD and heat shock proteins, also commonly identified in several plant-pathogen proteomic studies described in this review (Fig. 1).

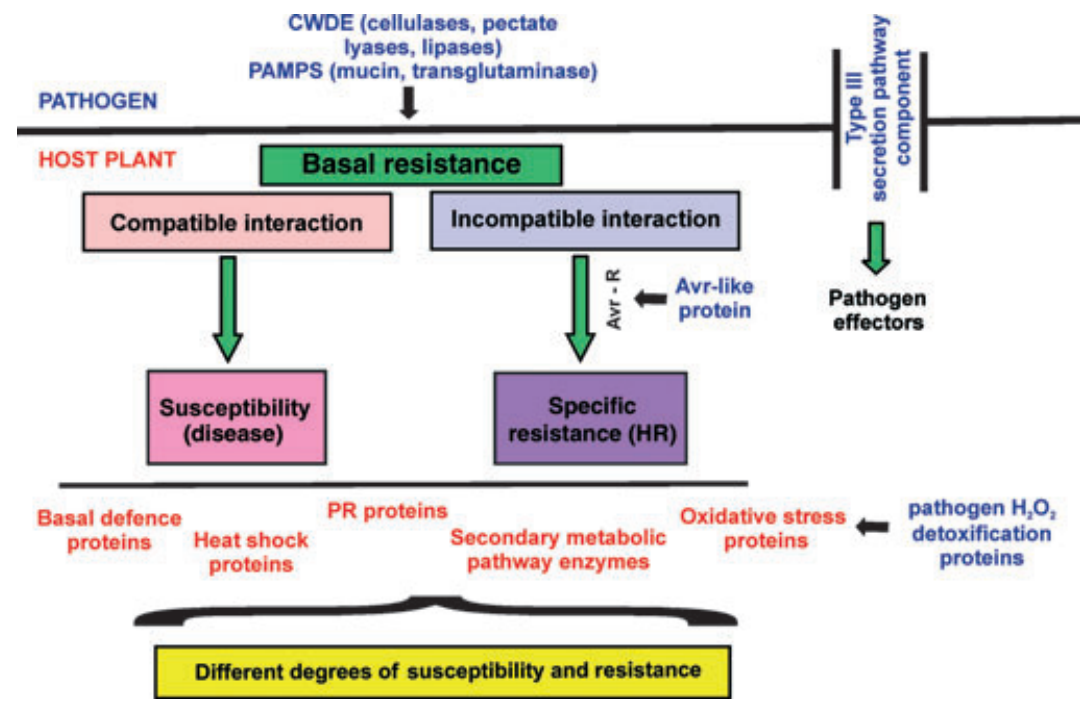

Fig. 1. Overview of plant-pathogen interactions and insights into proteomic studies of the proteins involved in these processes. Plants possess receptors that can activate basal resistance, mediated by pathogen-associated molecular patterns (PAMPs) or cell wall-degrading enzymes (CWDEs), which may result in a compatible or incompatible interaction. In both interactions, several defence-related and biotic stress-responsive proteins are induced. Suppression of plant defences by pathogen effectors leads to susceptibility in host plants. Some host plants express resistance (R) proteins, which guard against this interference and trigger a specific resistance, referred to as the hypersensitive response (HR). Proteomic studies of plant-pathogen interactions have revealed several pathogen and plant proteins expressed in different pathosystems. These proteins, identified using proteomic tools, are highlighted in blue (pathogen) and red (plant) in the different stages of the interaction. 
Although several proteins expressed during plantpathogen interactions have been highlighted, most are well known and are mainly involved in the conflict between the pathogen and the plant to suppress or induce, respectively, the basal plant defence mechanism. The results that emerge from most proteomic analyses are of extreme importance for the validation of the expression of the genes identified by genomic or transcriptomic studies. However, a small amount of novel information has been obtained, and can be explained by the fact that key proteins are expressed in low abundance, and are therefore not detected by current proteomic tools. Indeed, only the most abundant proteins are detected in two-dimensional gels and successfully identified by MS. Another major problem faced in proteomic analyses is protein identification by peptide mass fingerprinting. Unequivocal identification is usually obtained only when the genome sequence or a large amount of sequence data are available in public databases. When analysing poorly studied organisms, identification must be performed by de novo sequencing, which requires more sophisticated equipment, not readily available, especially in developing countries. Therefore, a gap appears to exist in the bioinformatics pipeline for the proteomics of organisms with incomplete sequenced genomes. These technical limitations in proteomic studies need to be overcome in order to advance our knowledge on protein expression during plant-pathogen interactions. Nevertheless, proteomic tools are rapidly improving and new methods and equipment are being developed. We believe that future proteomic studies, coupled with functional validation analysis, may provide new insights into disease resistance and pathogenicity.

Another important aspect to be considered when performing proteomic analyses is the follow-up study of the identified proteins, which should be performed in order to correctly assign protein function. The multiple roles of proteins are a significant barrier to progress in the unambiguous identification of proteins involved in processes such as plant-pathogen interactions. Moreover, a frequent result found in proteomic studies is the large amount of proteins obtained with unknown function. It is important to further investigate these proteins, which may present new biological functions and may play important roles in the processes under investigation.

The examples reviewed here demonstrate the complex cellular network that exists in different plant-pathogen interactions. Overall, the use of proteomic studies, allied to functional validation analyses, can provide fascinating contributions to the understanding of complex mechanisms, such as plant-pathogen interactions. The first step in the understanding of disease resistance is currently being met with the identification of the proteins expressed during plant-pathogen interactions. The next step will be to determine which proteins confer pathogenicity and disease resistance, and the mechanisms by which they do so.

\section{Acknowledgements}

We wish to thank Dr Gilbert Engler for critical evaluation of the manuscript and English revision.

\section{References}

1 Alfano JR \& Collmer A (2004) Type III secretion system effector proteins: double agents in bacterial disease and plant defence. Annu Rev Phytol 42, 385-414.

2 Van Sluys MA, Monteiro-Vitorello CB, Camargo LEA, Menck CFM, Da Silva ACR, Ferro JA, Oliveira MC, Setubal JC, Kitajima JP \& Simpson AJ (2002) Comparative genomic analysis of plant-associated bacteria. Anпu Rev Phytol 40, 169-189.

3 Jones AME, Thomas V, Truman B, Lilley K, Mansfield J \& Grant M (2004) Specific changes in the Arabidopsis proteome in response to bacterial challenge: differentiating basal and R-gene mediated resistance. Phytochemistry 65, 1805-1816.

4 Whitham SA, Yang C \& Goodin MM (2006) Global impact: elucidating plant responses to viral infection. Mol Plant-Microbe Interact 19, 1207-1215.

5 Lee BJ, Kwon SJ, Kim SK, Kim KJ, Park CJ, Kim YJ, Park OK \& Paek KH (2006) Functional study of hot pepper 26S proteasome subunit RPN7 induced by tobacco mosaic virus from nuclear proteome analysis. Biochem Biophys Res Commun 351, 405-411.

6 Diaz-Vivancos P, Rubio M, Mesonero V, Periago PM, Barcelo AR, Martinez-Gomez P \& Hernandez JA (2006) The apoplastic antioxidant system in Prunus: response to long-term plum pox virus infection. $J$ Exp Bot 57, 3813-3824.

7 Rahoutei J, Barón M, García-Luque I, Droppa M, Neményi A \& Horvath G (1999) Effect of tobamovirus infection on the thermoluminescence characteristics of chloroplast from infected plants. Z Naturforsch Teil C 54, 634-639.

8 Rahoutei J, Garcia-Luque I \& Baron M (2000) Inhibition of photosynthesis by viral infection: effect on PSII structure and function. Physiol Plant 110, 286-292.

9 Perez-Bueno ML, Rahoutei J, Sajnani C, Garcia-Luque I \& Baron M (2004) Proteomic analysis of the oxygenevolving complex of photosystem II under biotic stress: studies on Nicotiana benthamiana infected with tobamoviruses. Proteomics 4, 418-425. 
10 Abbink TE, Peart JR, Mos TN, Baulcombe DC, Bol JF \& Linthorst HJ (2002) Silencing of a gene encoding a protein component of the oxygen-evolving complex of photosystem II enhances virus replication in plants. Virology 295, 307-319.

11 Delalande F, Carapito C, Brizard JP, Brugidou C \& Van Dorsselaer A (2005) Multigenic families and proteomics: extended protein characterization as a tool for paralog gene identification. Proteomics 5, 450-460.

12 Brizard JP, Carapito C, Delalande F, Van Dorsselaer A \& Brugidou C (2006) Proteome analysis of plant-virus interactome: comprehensive data for virus multiplication inside their hosts. Mol Cell Proteomics 5, 2279-2297.

13 Casado-Vela J, Selles S \& Martinez RB (2006) Proteomic analysis of tobacco mosaic virus-infected tomato (Lycopersicon esculentum M.) fruits and detection of viral coat protein. Proteomics 6(Suppl. 1), S196-S206.

14 Lee VT \& Schneewind O (2001) Protein secretion and the pathogenesis of bacterial infections. Genes Dev 15, 1725-1752.

15 Pühler A, Arlat M, Becker A, Göttfert M, Morrissey JP \& O'Gara F (2004) What can bacterial genome research teach us about bacteria-plant interactions? Curr Opin Plant Biol 7, 137-147.

16 Galan JE \& Collmer A (1999) Type III secretion machines: bacterial devices for protein delivery into host cells. Science 284, 1322-1328.

17 Cornelis GR \& Van Gijsegem F (2000) Assembly and function of type III secretory systems. Annu Rev Microbiol 54, 735-774.

18 Keen NT (1990) Gene-for-gene complementarity in plant-pathogen interactions. Annu Rev Genet 24, 447463.

19 Staskawicz BJ, Dahlbeck D \& Keen NT (1984) Cloned avirulence gene of Pseudomonas syringae pv. glycinea determines race-specific incompatibility on Glycine max (L.) Merr. Proc Natl Acad Sci USA 81, 6024-6028.

20 Lahaye T \& Bonas U (2001) Molecular secrets of bacterial type III effector proteins. Trends Plant Sci 6, 479485.

21 Schechter LM, Roberts KA, Jamir Y, Alfano JR \& Collmer A (2004) Pseudomonas syringae type III secretion system targeting signals and novel effectors studied with a Cya translocation reporter. J Bacteriol 186, 543-555.

22 Noel L, Thieme F, Nennstiel D \& Bonas U (2001) cDNA-AFLP analysis unravels a genome-wide hrpGregulon in the plant pathogen Xanthomonas campestris pv. vesicatoria. Mol Microbiol 41, 1271-1281.

23 Alfano JR \& Collmer A (1997) The type III (Hrp) secretion pathway of plant pathogenic bacteria: trafficking harpins, Avr proteins, and death. J Bacteriol 179, 5655-5662.

24 Arlat M, Van Gijsegem F, Huet JC, Pernollet JC \& Boucher CA (1994) PopA1, a protein which induces a hypersensitivity-like response on specific Petunia genotypes, is secreted via the Hrp pathway of Pseudomonas solanacearum. EMBO J 13, 543-553.

25 Mehta A \& Rosato YB (2001) Differentially expressed proteins in the interaction of Xanthomonas axonopodis pv. citri with leaf extract of the host plant. Proteomics 1, 1111-1118.

26 Tahara ST, Mehta A \& Rosato YB (2003) Proteins induced by Xanthomonas axonopodis pv. passiflorae with leaf extract of the host plant (Passiflorae edulis). Proteomics 3, 95-102.

27 Babujee L, Venkatesh B, Yamazaki A \& Tsuyumu S (2007) Proteomic analysis of the carbonate insoluble outer membrane fraction of the soft-rot pathogen Dickeya dadantii (syn. Erwinia chrysanthemi) strain 3937. J Proteome Res 6, 62-69.

28 Russel M (1994) Mutants at conserved positions in gene IV, a gene required for assembly and secretion of filamentous phages. Mol Microbiol 14, 357-369.

29 Bouchart F, Delangle A, Lemoine J, Bohin JP \& Lacroix JM (2007) Proteomic analysis of a non-virulent mutant of the phytopathogenic bacterium Erwinia chrysanthemi deficient in osmoregulated periplasmic glucans: change in protein expression is not restricted to the envelope, but affects general metabolism. Microbiology 153, 760-767.

30 Martins D, Astua-Monge G, Coletta-Filho HD, Winck FV, Baldasso PA, de Oliveira BM, Marangoni S, Machado MA, Novello JC \& Smolka MB (2007) Absence of classical heat shock response in the citrus pathogen Xylella fastidiosa. Curr Microbiol 54, 119-123.

31 Kazemi-Pour N, Condemine G \& Hugouvieux-CottePattat N (2004) The secretome of the plant pathogenic bacterium Erwinia chrysanthemi. Proteomics 4, 31773186.

32 Watt SA, Wilke A, Patschkowski T \& Niehaus K (2005) Comprehensive analysis of the extracellular proteins from Xanthomonas campestris pv. campestris B100. Proteomics 5, 153-167.

33 Smolka MB, Martins D, Winck FV, Santoro CE, Castellari RR, Ferrari F, Brum IJ, Galembeck E, Della Coletta Filho H, Machado MA et al. (2003) Proteome analysis of the plant pathogen Xylella fastidiosa reveals major cellular and extracellular proteins and a peculiar codon bias distribution. Proteomics $\mathbf{3}$, 224-237.

34 Rosen R, Sacher A, Shechter N, Becher D, Buttner K, Biran D, Hecker M \& Ron EZ (2004) Two-dimensional reference map of Agrobacterium tumefaciens proteins. Proteomics 4, 1061-1073.

35 Jones AME, Thomas V, Bennett MH, Mansfield J \& Grant M (2006) Modifications to the Arabidopsis defence proteome occur prior to significant transcriptional change in response to inoculation with Pseudomonas syringae. Plant Physiol 142, 1603-1620. 
36 Mahmood T, Jan A, Kakishima M \& Komatsu S (2006) Proteomic analysis of bacterial-blight defenceresponsive proteins in rice leaf blades. Proteomics $\mathbf{6}$, 6053-6065.

37 Chen F, Yuan Y, Li Q \& He Z (2007) Proteomic analysis of rice plasma membrane reveals proteins involved in early defence response to bacterial blight. Proteomics 7, 1529-1539.

38 Coaker GL, Willard B, Kinter M, Stockinger EJ \& Francis DM (2004) Proteomic analysis of resistance mediated by Rcm 2.0 and Rcm 5.1, two loci controlling resistance to bacterial canker of tomato. Mol PlantMicrobe Interact 17, 1019-1028.

39 Mathesius U, Mulders S, Gao M, Teplitski M, Caetano-Anolles G, Rolfe BG \& Bauer WD (2003) Extensive and specific responses of a eukaryote to bacterial quorum-sensing signals. Proc Natl Acad Sci USA 100, 1444-1449.

40 Xing T, Ouellet TR \& Miki BL (2002) Towards genomic and proteomic studies of protein phosphorylation in plant-pathogen interactions. Trends Plant Sci 7, 224230.

41 Peck SC, Nühse TS, Hess D, Iglesias A, Meins F \& Boller T (2001) Directed proteomics identifies a plantspecific protein rapidly phosphorylated in response to bacterial and fungal elicitors. Plant Cell 13, 1467-1475.

42 Jones AME, Bennett MH, Mansfield JW \& Grant M (2006) Analysis of the defence phosphoproteome of Arabidopsis thaliana using differential mass tagging. Proteomics 6, 4155-4165.

43 Murad AM, Laumann RA, Lima Tde A, Sarmento RB, Noronha EF, Rocha TL, Valadares-Inglis MC \& Franco OL (2006) Screening of entomopathogenic Metarhizium anisopliae isolates and proteomic analysis of secretion synthesized in response to cowpea weevil (Callosobruchus maculatus) exoskeleton. Comp Biochem Physiol C Toxicol Pharmacol 142, 365-370.

44 Murad AM, Laumann RA, Mehta A, Noronha EF \& Franco OL (2007) Screening and secretomic analysis of entomopathogenic Beauveria bassiana isolates in response to cowpea weevil (Callosobruchus maculatus) exoskeleton. Comp Biochem Physiol C Toxicol Pharmacol 145, 333-338.

45 Bohmer M, Colby T, Bohmer C, Brautigam A, Schmidt J \& Bolker M (2007) Proteomic analysis of dimorphic transition in the phytopathogenic fungus Ustilago maydis. Proteomics 7, 675-685.

46 Grenville-Briggs LJ, Avrova AO, Bruce CR, Williams A, Whisson SC, Birch PR \& van West P (2005) Elevated amino acid biosynthesis in Phytophthora infestans during appressorium formation and potato infection. Fungal Genet Biol 42, 244-256.

47 Rampitsch C, Bykova NV, McCallum B, Beimcik E \& Ens W (2006) Analysis of the wheat and Puccinia triticina (leaf rust) proteomes during a susceptible host-pathogen interaction. Proteomics 6, 1897-1907.

48 Webb CA \& Fellers JP (2006) Cereal rust fungi genomics and the pursuit of virulence and avirulence factors. FEMS Microbiol Lett 264, 1-7.

49 Phalip V, Delalande F, Carapito C, Goubet F, Hatsch D, Leize-Wagner E, Dupree P, Dorsselaer AV \& Jeltsch JM (2005) Diversity of the exoproteome of Fusarium graminearum grown on plant cell wall. Curr Genet $\mathbf{4 8 ,}$ 366-379.

50 Meijer HJ, van de Vondervoort PJ, Yin QY, de Koster CG, Klis FM, Govers F \& de Groot PW (2006) Identification of cell wall-associated proteins from Phytophthora ramorum. Mol Plant-Microbe Interact 19, 1348-1358.

51 Yajima W \& Kav NN (2006) The proteome of the phytopathogenic fungus Sclerotinia sclerotiorum. Proteomics 6, 5995-6007.

52 Talbot NJ (2003) On the trail of a cereal killer: exploring the biology of Magnaporthe grisea. Annu Rev Microbiol 57, 177-202.

53 Konishi H, Ishiguro K \& Komatsu S (2001) A proteomics approach towards understanding blast fungus infection of rice grown under different levels of nitrogen fertilization. Proteomics 1, 1162-1171.

54 Long DH, Lee FN \& TeBeest DO (2000) Effect of nitrogen fertilization on disease progress of rice blast on susceptible and resistant cultivars. Plant Dis 84, 403409.

55 Rakwal R \& Agrawal GK (2003) Rice proteomics: current status and future perspectives. Electrophoresis 24, 3378-3389.

56 Kim ST, Cho KS, Yu S, Kim SG, Hong JC, Han CD, Bae DW, Nam MH \& Kang KY (2003) Proteomic analysis of differentially expressed proteins induced by rice blast fungus and elicitor in suspension-cultured rice cells. Proteomics 3, 2368-2378.

57 Kim ST, Kim SG, Hwang DH, Kang SY, Kim HJ, Lee BH, Lee JJ \& Kang KY (2004) Proteomic analysis of pathogen-responsive proteins from rice leaves induced by rice blast fungus, Magnaporthe grisea. Proteomics 4 , 3569-3578.

58 Lee J, Bricker TM, Lefevre M, Pinson SRM \& Oard JH (2006) Proteomic and genetic approaches to identify defence-related proteins in rice challenged with the fungal pathogen Rhizoctonia solani. Mol Plant Pathol 7, 405-416.

59 Zhou W, Eudes F \& Laroche A (2006) Identification of differentially regulated proteins in response to a compatible interaction between the pathogen Fusarium graminearum and its host, Triticum aestivum. Proteomics 6, 4599-4609.

60 Colditz F, Nyamsuren O, Niehaus K, Eubel H, Braun HP \& Krajinski F (2004) Proteomic approach: identification of Medicago truncatula proteins induced in roots 
after infection with the pathogenic oomycete Aphanomyces euteiches. Plant Mol Biol 55, 109-120.

61 Campo S, Carrascal M, Coca M, Abian J \& San Segundo B (2004) The defence response of germinating maize embryos against fungal infection: a proteomics approach. Proteomics 4, 383-396.

62 Houterman PM, Speijer D, Dekker HL, De Koster CG, Cornelissen BJC \& Rep M (2007) The mixed xylem sap proteome of Fusarium oxysporum-infected tomato plants. Mol Plant Pathol 8, 215-221.

63 Chitwood DJ (2003) Research on plant-parasitic nematode biology conducted by the United States Department of Agriculture-Agricultural Research Service. Pest Manag Sci 59, 748-753.

64 Curtis RH (2007) Plant parasitic nematode proteins and the host-parasite interaction. Brief Funct Genomic Proteomic 6, 50-58.

65 Smant G, Stokkermans JP, Yan Y, de Boer JM, Baum TJ, Wang X, Hussey RS, Gommers FJ, Henrissat B, Davis EL et al. (1998) Endogenous cellulases in animals: isolation of beta-1,4-endoglucanase genes from two species of plant-parasitic cyst nematodes. Proc Natl Acad Sci USA 95, 49064911.

66 Gao B, Allen R, Maier T, Davis EL, Baum TJ \& Hussey RS (2003) The parasitome of the phytonematode Heterodera glycines. Mol Plant-Microbe Interact 16, 720-726.

67 Huang G, Gao B, Maier T, Allen R, Davis EL, Baum TJ \& Hussey RS (2003) A profile of putative parasitism genes expressed in the esophageal gland cells of the root-knot nematode Meloidogyne incognita. Mol PlantMicrobe Interact 16, 376-381.

68 Tytgat T, Vercauteren I, Vanholme B, De Meutter J, Vanhoutte I, Gheysen G, Borgonie G, Coomans A \&
Gheysen G (2005) An SXP/RAL-2 protein produced by the subventral pharyngeal glands in the plant parasitic root-knot nematode Meloidogyne incognita. Parasitol Res 95, 50-54.

69 De Meutter J, Vanholme B, Bauw G, Tytgat T, Gheysen G \& Gheysen G (2001) Preparation and sequencing of secreted proteins from the pharyngeal glands of the plant parasitic nematode Heterodera schachtii. Mol Plant Pathol 2, 297-301.

70 Jaubert S, Ledger TN, Laffaire JB, Piotte C, Abad P \& Rosso MN (2002) Direct identification of stylet secreted proteins from root-knot nematodes by a proteomic approach. Mol Biochem Parasitol 121, 205-211.

71 Calvo E, Flores-Romero P, Lopez JA \& Navas A (2005) Identification of proteins expressing differences among isolates of Meloidogyne spp. (Nematoda: Meloidogynidae) by nano-liquid chromatography coupled to ion-trap mass spectrometry. J Proteome Res 4, 1017-1021.

72 Ashton PD, Curwen RS \& Wilson RA (2001) Linking proteome and genome: how to identify parasite proteins. Trends Parasitol 17, 198-202.

73 Williamson VM \& Kumar A (2006) Nematode resistance in plants: the battle underground. Trends Genet 22, 396-403.

74 Mehta A, Magalhães BS, Souza DSL, Vasconcelos EAR, Silva LP, Grossi-de-Sá MF, Franco OL, da Costa PHA \& Rocha TL (2008) Rooteomics: the challenge of discovering plant defence-related proteins in roots. Curr Prot Pep Sci 9, 108-116.

75 Chivasa S, Hamilton JM, Pringle RS, Ndimba BK, Simon WJ, Lindsey K \& Slabas AR (2006) Proteomic analysis of differentially expressed proteins in fungal elicitor-treated Arabidopsis cell cultures. J Exp Bot 57, $1553-1562$. 